\title{
EXPRESSION OF p53, p63 AND p73 IN THE OROFACIAL REGION OF HUMAN EMBRYOS
}

\author{
Drahomíra Černochová, Eva Pospíšilová, Dana Kylarová
}

\author{
Department of Histology and Embryology, Faculty of Medicine, Palacký University, Olomouc, Czech Republic \\ e-mail: cernod@tunw.upol.cz
}

Received: September 20, 2004

Key words: p53/p63/p73/Orofacial region

We studied p53, p63, p73 protein expression in the orofacial region of five human embryos aged 7-18 weeks of intrauterine development using a three-step immunohistochemical method. Expression of proteins in various locations was evaluated semiquantitatively.

A decrease in p53, p63 and p73 proteins occured in the 13-week-old material with the exception of the tooth germ where a drop in p73 appeared in the ninth week.

\section{INTRODUCTION}

P53 protein is assumed to be one of the most important regulators in response to various forms of cell stress. It takes part in the control of many cell processes, including cell cycle arrest, inhibition of DNA replication, control of differentiation, regulation of transcription and DNA reparation, maintaining the integrity of the genome and induction of programmed cell death ${ }^{1}$. Identification of two homologues, p63 and p73 has shown that p53 is a member of a family of related transcription factors.

P63 is highly expressed in embryonic ectoderm and in the basal regenerative layers of many epithelial tissues in the adult ${ }^{2}$.

P73 can activate p53 - regulated genes and suppress growth or induce apoptosis.

Since p53 and p73 are linked to different upstream pathways, this family of transcription factors might regulate a common set of genes in response to different extracellular signals and developmental cues ${ }^{3}$.

The above facts prompted us to map expression of these proteins in the orofacial region in human embryos at various developmental stages.

\section{MATERIAL AND METHODS}

Tissue samples of five human embryos (normal pregnancies) aged 7-18 weeks of intrauterine development (IUD) were fixed in methacarn and processed using classic paraffin techniques.

The immunohistochemical detection of proteins was performed by an indirect three-step immunohistochemical method using monoclonal antibodies (Masaryk Memorial Cancer Institute).

Expression of proteins in various locations was evaluated semiquantitatively.

\section{RESULTS AND DISCUSSION}

Expression of proteins was studied in the region of the dental lamina, of the dental organ, dental papilla and dental follicle, in the region of the vestibular lamina and in the region of the epithelium of the palate and palatal suture, in the differentiating mucosa of the dorsum of the tongue and in respiratory and olfactory regions of the developing nasal cavity in case that they were present in the section.

\section{EXPRESSION OF STUDIED PROTEINS IN VARIOUS LOCALIZATIONS}

Expression of p53 protein remained approximately constant from the seventh to eleventh week. The literature describes a decrease in p53 expression after the tenth week of IUD in other tissues and organs of human embryos ${ }^{4}$. We found a moderate decrease in expression in the 13 - week old material.

Expression of p63 increased from the seventh to the eleventh week, when a maximum of positive nuclei was found. A dramatic drop occurred in the thirteenth week.

Expression of p73 was distinct between seventh and the eleventh week in all the followed localities with the exception of the tooth germ, where a decrease appeared in the ninth week. In the other localities the expression disappears in the thirteenth week.

\section{ACKNOWLEDGEMENT}

The study was supported by grant MSMT 15100001. 
Table 1. Expression of studied proteins in various localizations

\begin{tabular}{|c|c|c|c|c|c|}
\hline \multirow[b]{2}{*}{ Localization } & \multicolumn{5}{|c|}{ Age (in weeks of IUD) } \\
\hline & 7 & 9 & 11 & 13 & 18 \\
\hline \multicolumn{6}{|l|}{$\mathrm{p53}$} \\
\hline $\begin{array}{l}\text { dental lamina } \\
\text { (dental organ) }\end{array}$ & ++++ & +++ & +++ & ++ & + \\
\hline $\begin{array}{l}\text { dental papilla and } \\
\text { dental follicle }\end{array}$ & +++ & +++ & +++ & +++ & 0 \\
\hline vestibular lamina & +++ & ++ & +++ & + & 0 \\
\hline plate and suture & +++ & +++ & - & - & - \\
\hline dorsum of the tongue & - & + & 0 & - & - \\
\hline \multirow{3}{*}{\begin{tabular}{|l}
\multicolumn{1}{c}{ nasal cavity } \\
- regio respiratoria \\
- regio olfactoria
\end{tabular}} & & & & & \\
\hline & +++ & +++ & ++ & - & - \\
\hline & +++ & - & ++ & - & - \\
\hline \multicolumn{6}{|l|}{ p63 } \\
\hline $\begin{array}{l}\text { dental lamina } \\
\text { (dental organ) }\end{array}$ & +++ & ++ & ++++ & + & 0 \\
\hline $\begin{array}{l}\text { dental papilla and } \\
\text { dental follicle }\end{array}$ & ++ & ++++ & ++ & + & 0 \\
\hline vestibular lamina & ++ & - & ++++ & + & - \\
\hline plate and suture & ++ & +++ & +++ & - & - \\
\hline dorsum of the tongue & ++ & - & ++++ & + & - \\
\hline \multirow{3}{*}{$\begin{array}{c}\text { nasal cavity } \\
\text { - regio respiratoria } \\
\text { - regio olfactoria }\end{array}$} & & & & & \\
\hline & ++ & - & ++++ & - & - \\
\hline & ++ & - & ++++ & - & - \\
\hline \multicolumn{6}{|l|}{ p73 } \\
\hline $\begin{array}{l}\text { dental lamina } \\
\text { (dental organ) }\end{array}$ & +++ & + & + & 0 & 0 \\
\hline $\begin{array}{l}\text { dental papilla and } \\
\text { dental follicle }\end{array}$ & + & +++ & ++ & 0 & 0 \\
\hline vestibular lamina & ++ & ++ & +++ & 0 & - \\
\hline plate and suture & +++ & ++++ & ++ & 0 & - \\
\hline dorsum of the tongue & ++++ & ++ & ++ & 0 & - \\
\hline \multirow{3}{*}{$\begin{array}{c}\text { nasal cavity } \\
\text { - regio respiratoria } \\
\text { - regio olfactoria }\end{array}$} & & & & & \\
\hline & +++ & - & - & - & - \\
\hline & ++ & - & - & - & - \\
\hline
\end{tabular}

Legend: Frequency of occurrence of positive nuclei is expressed by count of +

$\begin{array}{clcl}++++ & \text { massive } & ++ & \text { isolated groups } \\ +++ & \text { diffuse } & + & \text { single } \\ 0 & \text { no occurrence } & - & \text { area missing in section }\end{array}$

\section{REFERENCES}

1. Uldrijan S, Kotala V, Vojtěšek B. (2002) Regulace stability a aktivity nádorového supresoru p53. Chem Listy 96, 145-149.

2. van Bokhoven H, McKeon F. (2002) Mutations in the p53 homolog p63: allele-specific developmental syndromes in humans. TRENDS in Molecular Medicine 8, No. 3, 133-139.

3. Levrero M, De Laurenzi V, Constanzo A, Sabatini S, Gong J, Wang JYJ, Melino G. (2000) The p53/p63/p73 family of transcription factors: overlapping and distinct functions. J Cell Sci 113, 1661-1670.

4. Lichnovský V, Koláŕ Z, Murray P, Hlobilková A, Černochová D, Pospíšilová E, Vojtěšek B, Nenutil R. (1998) Differences in p53 and $\mathrm{Bcl}-2$ expression in relation to cell proliferation during the development of human embryos. Molecular Pathology, Vol. 51, No. 3, 131-137. 